песни им. Валерия Грушина, Грушинский фестиваль. Согласно правилам русской орфографии, индивидуализирующий компонент должен выделяться кавычками, которые могут отсутствовать: Фестиваль активного отдыха Жигулевское море. Зима-2017. Границы этого разряда онимов размыты, поскольку контексты не всегда содержат признаки проприального статуса рассматриваемых наименований.

Врублевская О. В. Языковая мода в русской ономастике : дис. ... д-ра филол. наук / Волгогр. гос. соц.-пед. ун-т. Волгоград, 2017.

Подольская Н. В. Словарь русской ономастической терминологии. М., 1988.

Хоффманн Э. Имена политических событий и их онимизация в средствах массовой информации // Вопр. ономастики. 2008. № 5. С. 90-104.

Donec P. N. Zum Begriff des Eventonyms // Das Wort: Germanistisches Jahrbuch der GUS. 2002. P. 35-41.

DOI $10.31168 / 7996-2700-3.106$

\author{
И. И. Русинова \\ Пермский государственный национальный \\ исследовательский университет \\ Пермь, Россия \\ irusinova@mail.ru
}

\title{
Ойкать, ахать и охать: семантика причинения магического вреда (по данным русских диалектных словарей и мифологических текстов)
}

Вредоносное магическое влияние на человека, хозяйство и скот, по представлениям носителей традиционной крестьянской культуры, может осуществляться по-разному. Основными видами такого воздействия у славян являются порча и сглаз. По данным словаря «Славянские древности», вредоносный результат порчи «достигается с помощью разных форм контактной магии, сглаз осуществляется исключительно нематериальными способами воздействия и не обязательно злонамеренно» [Левкиевская, 2009, 597].

В докладе рассмотрена семантика глагольной лексики междометного происхождения, в которой реализуется идея сглаза через похвалу. (С Русинова И. И., 2019 
В современном обществе (причем не только традиционном) существуют коммуникативные правила, нарушение которых может привести к сглазу. Одно из таких правил - запрет на похвалу, особенно маленьких детей и молодняка скотины. Считается, что особой вредоносностью обладает похвала, выраженная излишне эмоционально и сопровождаемая восклицаниями oŭ, $a x, o x$, ср.: «Дочь у меня маленькая ещё была. У нас тоже вот родственница. А говорят, ребёнка ведь с ходу нельзя хвалить. Она зашла, пошла на автобус и бегом-бегомбегом: “Ox, ax!” — и ушла. Она <т. е. дочь> у меня разревелась, разревелась, ничего не помогает» (с. Усть-Зула Юрлинского района ${ }^{1}$ ) [ФА ПГНИУ]; «У меня первый сын рос, он до ц'его глазу боялся, он у меня такой полный мальчишка, хороший. Пришла соседка: “Ой, Славик, какой ты большой, хороший!” < .. > Вот я сутки не могла ниц'его с ним сделать» (д. Евсино Юсьвинского района) [Знатки, 158]. При этом наиболее строгий запрет налагается на междометие ой, сопровождающее похвалу: «Вот “ой” - самое противное слово. Скажут: “Ой, какой у вас ребёночек хороший!”, глядь — а ребёнок уж заболел» (с. Романово Ильинского района) [ФА ПГНИУ]; «“Ой” говорить не положено, лучше скажи “Ох!”» (Верещагинский район) [Христофорова, 2010, 322].

Междометия ой, ox и ах послужили деривационной базой глаголов, обозначающих восклицание для выражения неожиданной радости, удивления, испуга и т. п. Однако в русских мифологических текстах о сглазе семантика этих глаголов иная. Сема говорения дополняется другой - семой причинения магического вреда. Следовательно, глаголы ойкать, axamb, oxamb можно истолковать следующим образом: 'произносить сопровождающие похвалу восклицания «ой», «ах», «ох», тем самым (обычно непроизвольно) причиняя вред кому-, чему-л.': «Нельзя ойкать, чтоб не изурочить» (пос. Юго-Камский Пермского района); «Козу изурочили: “Коза да коза”. Чё охать да ахать! Вот и испортили!» (с. Ермия Чернушинского района) [ФА ПГНИУ].

На основе данных глаголов возникают другие, образованные по модели «о-/об- + отмеждометный глагол», которые выражают идею причинения магического вреда более отчетливо, например глагол обойкать: «Не ойкай над ребёнком. Говорить “ой” нельзя. <Почему?> Ну почему-то нам всегда так говорили. Обойкивать не надо»

1 Здесь и далее: населенные пункты относятся к Пермскому краю. 
(Т. Н. Туктамышева, Пермь; запись предоставлена Ю. В. Зверевой). Надо сказать, что данная модель, в которой принимают участие глаголы речи, в русских говорах довольно активна. По данным [СРНГ, 22, 332-333; 23, 87, 102], это оговорить, озевать, озыкать, озычать и др., имеющие значение 'сглазить'. В пермских мифологических текстах есть глагол окаркать с тем же значением. Как правило, глаголы образованы от слов, обозначающих громкие, резкие звуки. В соответствии с данной моделью могут возникать единицы, корни которых называют и другие способы причинения магического вреда: одумать, обсмеять, обхохотать (д. Евсино Юсьвинского района) [Знатки, 158], обзарить, обизорить [СРНГ, 22, 52, 62].

Проанализировав данные диалектных словарей и тексты русских мифологических рассказов, мы пришли к следующему выводу: глагольная лексика, выражающая в русской языковой традиции идею сглаза словом, часто содержит семы, указывающие на чрезмерную силу эмоций. Уже сама похвала является отходом от нормативного коммуникативного поведения, а похвала, выраженная эмоционально, тем более. Вообще действия, сопровождаемые сильными чувствами, эмоциями, в традиционном обществе не приветствуются. Стоит вспомнить в связи с этим проклятия, «посылания» ребенка к лешему и т. п. В таких текстах выражается не только идея причинения вреда объекту злопожелания, но и повышенная экспрессия. Точно так же традицией ограничивается длительное выражение вдовой скорби, тоски по умершему мужу, сопровождаемой сильными чувствами, слезами, и т. п.

Знатки, ведуны и чернокнижники: колдовство и бытовая магия на Русском Севере / под общ. ред. А. Б. Мороза. М., 2013.

Левкиевская E. E. Сглаз // Славянские древности : этнолингв. словарь : в 5 т. / под общ. ред. Н. И. Толстого. Т. 4. М., 2009. С. 597.

СРНГ - Словарь русских народных говоров / гл. ред. Ф. П. Филин (вып. 1-22) ; Ф. П. Сороколетов (вып. 23-42) ; С. А. Мызников (вып. 43-). М. ; Л. ; СПб., 1965-. Вып. 1-.

ФА ПГНИУ - фольклорный архив Перм. гос. нац. исслед. ун-та (Пермь).

Христофорова О. Б. Колдуны и жертвы: Антропология колдовства в современной России. М., 2010. 